AT-TAJDID: Jurnal Pendidikan Dan Pemikiran Islam

(p-ISSN: 2548-5784 le-ISSN: 2549-2101)

Vol. (04 ) (02), (Desember) (2020), (Halaman) (140-158)

Doi: http://dx.doi.org/10.24127/att.v4.i02.1418

\title{
URGENSI STANDARISASI ISLAM ASWAJA ANNAHDLIYYAH UNTUK PERDAMAIAN INDONESIA DAN DUNIA
}

\author{
Mohammad Fadil \\ Universitas Islam Raden Rahmat Malang \\ E-mail : fadilahmad802@gmail.com
}

\begin{abstract}
ABSTRAK
Penulisan karya tulis ini bertujuan untuk mengajak siapapun tanpa tebang pilih agar lebih dekat dengan Nahdlatul Ulama, sebuah organisasi masyarakat yang salah satu tujuan dilahirkannya adalah demi melembagakan wawasan keagamaan yang dianut sebelumnya yakni A hlussunnah wal Jama'ah dan juga demi memenuhi kebutuhan perdamaian dunia di mana dewasa ini sangat rawan terhadap perpecahan akibat berbagai kepentingan mulai dari perbedaan pandangan politik, sosial, hingga kultur. Adapun yang menjadi latar belakang penulisan karya tulis ini adalah memaparkan betapa urgennya peran Islam Nahdlatul Ulama (An-Nahdliyyah) berpaham Aswaja bagi perdamaian dunia, khususnya bagi Negara Indonesia dengan background kemajemukan serta keberagamannya. Indonesia menjadi negara demokrasi dengan segala perbedaan dan kemajemukan yang ada, tetapi tetap bersatu padu, menciptakan kedamaian dalam satu bingkai kebangsaan. Indonesia bisa menjadi role model bagi negara-negara di dunia, khususnya bagi negara konflik dengan isu agama, bahwa perdamaian dan persatuan adalah perlu demi menjaga keutuhan suatu bangsa, dan Indonesia telah membuktikan harmoni itu. Selain sebab ideologi Pancasila yang terbukti mampu menyatukan perbedaan, Indonesia juga memiliki organisasi sebesar Nahdlatul Ulama yang telah terbukti hadir menjawab tantangan perbedaan. Nahdlatul Ulama merupakan organisasi masyarakat yang ramah, tidak marah. Merangkul, bukan memukul. Keberadaannya di tengah masyarakat mampu menjadi oase yang menyejukkan, dan menjadi garda terdepan dalam menjaga perdamaian serta keutuhan bangsa, sebagaimana yang tertuang dalam butir prinsip-prinsip yang selama ini Nahdlatul Ulama pegang teguh.
\end{abstract}

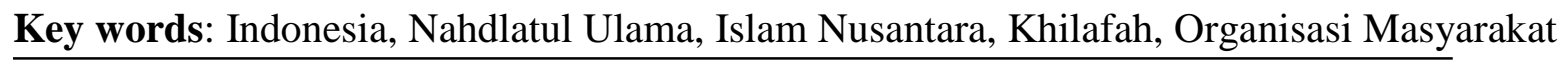

\begin{abstract}
The purpose of writing this paper is to invite anyone without selective logging to be closer to Nahdlatul Ulama, a community organization whose purpose was to institutionalize the previously held religious insight, namely A hlussunnah wal Jama'ah and also to meet the needs of world peace where today it is very prone to splits due to various interests ranging from differences in political, social, to cultural views. As for the background of the writing of this paper, it describes the importance of the role of the Islamic Nahdlatul Ulama (An-Nahdliyyah) with Aswaja ideology for
\end{abstract}


world peace, especially for the State of Indonesia with its plurality and diversity of background. Indonesia has become a democracy with all the differences and diversity that exists, but remains united, creating peace within one national frame. Indonesia can be a role model for countries in the world, especially for countries with religious issues, that peace and unity are necessary for the sake of maintaining the integrity of a nation, and Indonesia has proven that harmony. Apart from the fact that the Pancasila ideology is proven to be able to unite differences, Indonesia also has an organization the size of Nahdlatul Ulama which has been proven to be present to answer the challenges of difference. Nahdlatul Ulama is a friendly, non-angry community organization. Embrace, not beat. Its existence in the community is capable of being a soothing oasis and at the forefront of maintaining the peace and integrity of the nation, as stated in the points of principle that Nahdlatul Ulama has so far upheld.

Key words: Indonesia, Nahdlatul Ulama, Islam Nusantara, Khilafah, Community Organizations

\section{A. PENDAhULUAN}

Indonesia merupakan Negara kesatuan berpenduduk terbesar ke-4 di dunia. Berdasarkan catatan Wikipedia pada tahun 2018, populasi Indonesia berjumlah hampir 270.054.853 jiwa, terdiri dari kurang lebih 300 suku, sekitar 700 bahasa (daerah), serta 6 agama yang diakui. Keberagaman Indonesia demikian benar tak terbantahkan.

Sebagai Negara yang lahir dari keberagaman serta dengan background kemajemukan, adanya gesekan antar satu individu dengan individu lain, atau antar satu kelompok dengan kelompok lain dalam skala kecil dan dalam taraf yang wajar mungkin saja (pernah) terjadi, tetapi hal tersebut sebatas dinamika yang tidak sampai menimbulkan perpecahan maupun mengganggu jalannya stabilitas nasional.

Indonesia yang menganut semboyan Bhineka Tunggal Ika (berbeda-beda tetapi tetap satu jua) dan menjadikan Pancasila sebagai ideologi serta dasar negara, tetap menghadirkan kedamaian serta wajah yang ramah. Hal ini sesuai dengan sila ke-3 Pancasila yang berbunyi 'Persatuan Indonesia'.
Sudah bukan menjadi rahasia lagi jika selain memiliki kekayaan alam yang melimpah, Indonesia juga menjadi negara berpenduduk muslim terbesar di dunia. Berdasarkan data Wikipedia, jumlah muslim Indonesia terdiri lebih dari 230 juta jiwa. Artinya, 80\% lebih penduduk Indonesia dari total keseluruhan adalah muslim.

Artinya, Islam merupakan agama mayoritas. Islam menjadi agama yang banyak dianut penduduknya, tetapi hal demikian tidak lantas menjadikan Indonesia sebagai Negara Islam. Indonesia tetap negara demokrasi yang menjunjung tinggi keberagaman.

Ada banyak masjid yang berdiri di setiap sudut wilayah di Indonesia, tetapi bukan berarti gereja, pura, vihara, maupun tempat ibadah pemeluk agama lain tidak diperkenankan. Justru dapat berdiri berdampingan.

Memeluk suatu agama bagi rakyat Indonesia merupakan preferensi personal, tanpa adanya paksaan dari pihak manapun untuk memiliki keyakinannya sendiri. Hal ini sesuai dengan yang tertuang dalam UUD 1945 pasal 29 ayat 2, di mana setiap warga 
diberi kemerdekaan atau kebebasan untuk memeluk agamanya masing-masing dan beribadat menurut agama dan kepercayaan masing-masing.

Keberagaman adalah fitrah. Indonesia telah menyikapi perbedaan dengan bijak dan dewasa, sehingga yang tampak dari perbedaan tersebut adalah keindahan. Sebab persatuan dan kesatuan suatu negara adalah harga mati, tidak ada yang lebih penting dan genting dari itu sebagai bahan bakar menjaga keutuhan dalam perbedaan.

Sebagai agama yang rahmatan lil alamin, Islam turut memberikan kontribusi dalam menjaga keutuhan Negara Indonesia. Keberdaannya sebagai mayoritas bukan suatu halangan untuk tidak menggandeng kelompok minoritas, bersama membangun bangsa.

Lantas, bagaimana itu mungkin? Bukankah di negara-negara yang disinyalir merupakan pusat islam, kental dengan nuansa islam, atau mendapat predikat sebagai Negara Islam sendiri, justru terjadi perpecahan antar sesama kelompok maupun sesama saudara seiman? Beberapa juga terjadi tindak makar terhadap pemerintah? Sebut saja Suriah, Afghanistan, Irak, dan negara-negara konflik di Timur Tengah lain.

Ini tentu menjadi pembahasan menarik. Indonesia yang notabene beragam dalam segala lini dan dengan pemeluk muslimnya yang menonjol, tetapi dapat tetap bersatu, menjaga perdamaian demi keutuhan bangsa.

Bukan sebatas tugas pemerintah, menjaga perdamaian demi keutuhan bangsa sudah menjadi tugas utama dari salah satu organisasi masyarakat terbesar di Indonesia.

Adalah Nahdlatul Ulama (NU), sebuah organisasi Islam terbesar di Indonesia yang telah didirikan oleh Ulama besar KH. Hasyim Asy'ari bersama wali-wali Allah lain, tidak dapat dipungkiri telah banyak berkontribusi dan turut andil dalam menjaga perdamaian dunia, khususnya di Indonesia, sejak awal mula kelahirannya, hingga detik ini.

Sebab konsep tawassuth (moderat), tawazun (keseimbangan), I'tidal (tegak lurus/adil), serta tasammuh (toleran), dan Amar Ma'ruf Nahi Munkar, adalah prinsipprinsip dalam bermasyarakat serta bernegara yang telah dipegang teguh oleh Nahdlatul Ulama dan sangat relevan diterapkan dalam segala situasi juga tempat, terlebih di Indonesia dengan kemajemukannya.

Dengan prinsip-prinsip bermasyarakat serta bernegara tersebut, Nahdlatul Ulama hadir sebagai sebuah organisasi besar yang ramah dan santun terhadap siapapun, merangkul mereka yang dianggap minoritas, menggandeng mereka yang merasa dalam tindak diskriminatif.

Dengan berpegang pada prinsip-prinsip bermasyarakat serta bernegara tersebut, Nahdlatul Ulama hadir dalam pusaran keseimbangan, tidak terlalu ekstrem kanan yang cenderung radikal, tidak pula ekstrem kiri yang cenderung liberal.

Demikian, dalam menyikapi persoalan, metode pemikiran yang berkembang di kalangan NU adalah menggunakan lima cara, yakni; pemikiran moderat (fikrah tawassuthiyah), pemikiran toleran (fikrah tasamuhiyah), pemikiran reformatif (fikrah ishlahiyyah), pemikran dinamis (fikrah tathawwuriyah), dan pemikiran metodologis (fikrah manhajiyyah).

Rais 'Aam PBNU (2015-2020), KH. Dr. (HC) Ma'ruf Amin menjelaskan, salah satu karakter NU itu dinamis (tathawwuri), 
bukan tekstualis dan tidak liberalis, tetapi metodologis (manhaji). Menurutnya, NU mengakomodasi tradisi selagi tidak bertentangan dengan nash. NU tidak seperti Salafi-Wahabi yang tekstualis, tidak seperti kelompok takfiri yang radikalis, tidak seperti liberal yang mengubah-ubah nash. (Tim Aswaja NU Center PWNU Jawa Timur, 2016)

Nahdlatul Ulama merupakan rumah ramah yang bisa disinggahi siapapun, ilmu yang dapat dipelajari siapapun, buku yang bisa dibaca siapapun. Nahdlatul Ulama bisa dijadikan solusi bagi siapapun.

Berikut poin-poin besar Nahdlatul Ulama yang membuat keberadaannya patut diperhitungkan serta telah menjadi standar ideal bagi perdamaian dunia, khususnya Indonesia.

\section{B. PEMBAHASAN}

Nahdlatul Ulama merupakan organisasi yang berupaya melembagakan wawasan keagaam yang dianut sebelumnya, yakni paham Ahlus Sunnah wal Jama'ah, dengan menjadikan al-Qur'an dan al-Hadist sebagai pedoman serta Ijma' dan Qiyas sebagai rujukan dalam menentukan suatu kebijakan serta hukum yang disesuaikan dengan kultur maupun relevansi zaman.

Dalam bidang fiqih, NU sebagai organisasi yang bermanhaj, mengikuti manhaj salah satu dari empat mazhab yakni Imam Syafi'I, Imam Malik, Imam Hanafi, dan Imam Hanbali. Dalam tauhid mengikuti mazhab al-Imam Abu al-Hasan al-Asy'ari dan al-Imam Abu Manshur al-Maturidi serta yang sejalan dengan keduanya. Sementara dalam tasawwuf, sesuai mazhab Imam alGhazali, Junaid al-Baghdadi, serta yang sejalan dengan keduanya. (Tim Aswaja NU Center PWNU Jawa Timur, 2016)

Nahdlatul Ulama merupakan organisasi besar di Indonesia dengan jumlah massa/jamaah (nahdliyyin) di atas 90 juta, data berdasarkan Wikipedia pada 2015. Sementara berdasarkan survey Alvara Research Center menyebutkan jika NU berada di urutan pertama dari tiga besar Top of Mind Organisasi Islam di Indonesia dengan jumlah 69,3 persen (Survei: $N U$, Muhammadiyyah, dan FPI Tiga Besar "Top of Mind" Organisasi Islam di Indonesia, kompas.com, 2017). Mengingat kembali jika Indonesia adalah negara berpenduduk muslim terbesar di dunia, maka ada potensi jika Nahdlatul Ulama juga menjadi organisasi Islam besar di dunia.

Sebenarnya bukan menyoal besaran kuantitas, tetapi sebagai organisasi kemasyarakatan dan keagamaan yang besar, Nahdlatul Ulama tetap ramah dan melebarkan sayap perdamaian. Organisasi yang lahir pada 31 Januari 1926 ini memang inisiatif para ulama dalam mengawal terjaganya Islam Nusantara (di Indonesia), merawat keutuhan Negara Kesatuan Republik Indonesia (NKRI), serta upaya mempertahankan ajaran ahlus sunnah wal jamaah (Sejarah Berdirinya Nahdlatul Ulama, liputanislam.com; 2019).

Sebagai jama'ah (komunitas) dan sebagai jam'iyah (organisasi), Nahdlatul Ulama hadir demi memenuhi kepedulian terhadap umat. Sejak awal, NU didirikan untuk kepentingan umat. Pada tahun 1939, Kiai Abdullah Shiddiq menegaskan bahwa NU harus tetap menjadi organisasi rakyat yang sejati yang bisa hidup bersama rakyat 
kecil (Menjadikan NU Sebagai Organisasi Umat, nu.or.id, 2010).

Sebelum Nahdlatul Ulama lahir, KH. Wahab Hasbullah yang merupakan salah satu pendiri NU, bersama KH. Mas Manshur merintis organisasi pendidikan bernama Nahdlatul Wathan (Kebangkitan Tanah Air) pada 1914 M yang lebih banyak bergerak di bidang pendidikan islam, pembentukan kader dan pembinaan mubaligh atau juru dakwah dalam rangka menumbuhkan jiwa nasionalisme sebagai upaya untuk memperkuat perjuangan melawan penjajah.

Selain Nahdlatul Wathan, bersama KH. Ahmad Dahlan KH. Wahab Hasbullah juga mendirikan Tasywirul Afkar (Ekspresi Pemikiran) yang lebih banyak mengadakan diskusi-diskusi keagamaan dan sosial kemasyarakatan. Kiyai Wahab mengembangkan Nahdlatul Wathan ke berbagai daerah, membentuk cabang-cabang baru seperti Akhul Wathan di Semarang, Far'ul Wathan di Gresik, Hidayatul Wathan di Jombang, Far'ul Wathan di Malang, Ahlul Wathon di Wonokromo, Khitabatul Wathan di Pacarkeling, dan Hidayatul Wathan di Jagalan. Semua nama cabang mencantumkan nama wathan (tanah air). Hal ini menunjukkan bahwa madrasah memiliki misi tertentu yakni membangun semangat cinta tanah air. Aktivitas KH. Wahab Hasbullah di atas menunjukkan semangat kebangsaan yang nantinya terwujud dalam pembentukan Nahdlatul Ulama.

Kelahiran NU selain karena faktor mempertahankan Islam Ahlussunnh Wal Jama'ah, juga dilatarbelakangi semangat kebangsaan para ulama untuk merebut kemerdekaan bangsa dari penindasan penjajah. (Tim Aswaja NU Center PWNU Jawa Timur, 2016).

Dengan demikian kredibilitas serta kapabilitas Nahdlatul Ulama sebagai organisasi yang hadir untuk menyatukan bangsa sudah bukan perkara baru lagi.

\section{Kiprah Nahdlatul Ulama dalam sejarah dan perjuangan kemerdekaaan}

Dalam setiap periode sejarah di Indonesia, Nahdlatul Ulama selalu mengambil peran, terutama saat Indonesia mengalami masa-masa genting dalam cengkeraman penjajah dan kolonialisme.

Kiprah Nahdlatul Ulama tidak dapat dipandang sebelah mata. Terutama sejak kedatangan Jepang, keberadaan NU semakin diperhitungkan. Puluhan ribu anggota NU turut terlibat dalam latihan militer PETA. Tokoh-tokoh NU juga teribat dalam mengisi kemerdekaan sebagai anggota BPUPKI dan PPKI (Peran dan Perjuangan Nahdlatul Ulama (NU) Masa Kemerdekaan, wawasansejarah.com, 2016).

Pasca kemerdekaan, tantangan negara bukan semakin mudah, Indonesia mendapat tantangan yang lebih berat saat muncul penjajahan lain dalam bentuk pemberontakan terhadap pemerintahan yang sah dari komunisme yang mewujud dalam Partai Komunis Indonesia.

PKI yang paling bertanggung jawab atas kematian banyak tokoh penting di Indonesia, termasuk para pahlawan revolusi, ulama, dan santri. Atas kekejian tersebut, pada tahun 1960-an NU menuntut kepada pemerintah agar PKI dibubarkan, pada akhirnya pecah G 30 September 1945 (Khazanah Aswaja; 457) atau yang akrab disebut G30S/PKI. 
Sepenggal kisah keterlibatan NU dalam pusaran sejarah perjuangan kemerdekaan serta dalam mempertahankan kedaulatan Negara merupakan bukti nasionalisme dan patriotisme yang tidak dapat diragukan lagi.

Semangat nasionalisme dan patriotisme yang ditunjukkan NU tentu tidak lepas dari peran Hadlratus Syaikh K.H Hasyim Asy'ari yang merupakan Ra' is 'Aam sekaligus pendiri Nahdlatul Ulama. Kiyai Hasyim merupakan otak di balik tercetusnya Resolusi Jihad pada 22 Oktober 1945 (Tim Aswaja NU Center PWNU Jawa Timur, 2016).

Resolusi Jihad difatwakan untuk mempertahankan Negara Indonesia yang baru saja merdeka, menyatakan bahwa perjuangan untuk merdeka adalah perang suci (jihad), sebagai bentuk pertentangan keras terhadap kebangkitan kolonialisme di Indonesia. Perang melawan penjajah dihukumi wajib secara individu (fardlu 'ain) dan dianggap mati syahid bagi siapapun yang gugur dalam perang melawan penjajahan.

Resolusi Jihad merupakan bentuk seruan dari para ulama yang dipimpin $\mathrm{KH}$. Hasyim Asy'ari untuk melawan penjajah, yang mana naskahnya sendiri terdiri dari 2 macam, pertama berisi tentang permohonan kepada pemerintah Republik Indonesia agar menentukan sikap dan tindakan yang nyata terhadap usaha-usaha yang membahayakan kemerdekaan, agama, dan Negara Indonesia serta melanjutkan perjuangan "sabilillah" untuk tegaknya NKRI dan agama Islam. Kedua, berisi tentang hukum fardlu 'ain menolak dan melawan penjajah. (Tim Aswaja NU Center PWNU Jawa Timur, 2016)
Melalui Resolusi Jihad ini, Kiyai Hasyim terbukti mampu menggerakkan rakyat untuk melawan penjajah Belanda. Pada puncaknya, Fatwa Jihad atau lebih akrab disebut Resolusi Jihad tersebut menjadi pemicu pecahnya perang Arek-Arek Suroboyo yang dipimpin oleh Bung Tomo pada 10 november 1945.

Resolusi Jihad telah memantik Belanda untuk mengancam membui Kiyai Hasyim, tetapi Kiyai karismatik tersebut bergeming, bahkan saat Bung Tomo memintanya mengungsi dari Jombang demi menghindari ancaman Belanda, beliau tetap bertahan hingga titik darah penghabisan. Sikap juang Kiyai Hasyim inilah yang kemudian memunculkan kaidah popular, terutama di kalangan Nahdliyyin, yang berbunyi $H u b b$ al-Wathan Min al-Iman, yang bermakna; cinta tanah air sebagian dari iman.

Spirit nasionalisme dan patriotisme yang ditunjukkan Kiyai Hasyim khususnya, dan kalangan Nahdliyyin pada umumnya, menjadi bahan bakar dalam terciptanya keutuhan bangsa dan tanah air. Rasa cinta terhadap tanah air, menumbuhkan semangat nasionalisme serta patriotism.

Cinta tanah air yang digalakkan Nahdliyyin hingga kini merupakan bentuk implementasi dari cinta tanah air yang pernah diteladankan Kiyai Hasyim. Jihad yang pernah Kiyai Hasyim dan NU lalui dalam pusaran sejarah kemerdekaan, kini diterapkan oleh NU dengan jihad dalam bentuk lain, yakni menjaga persatuan dan kesatuan, sehingga tercipta kedamain.

\section{Dukungan NU terhadap Pancasila}

Salah satu faktor utama mengapa Indonesia tetap bersatu padu meski komposisi rakyatnya beragam adalah sebab 
adanya Pancasila yang dijadikan sebagai dasar Negara. Pancasila merupakan pemersatu bangsa yang tidak dapat ditawar lagi dengan berbagai bentuk falsafah serta ideologi lain, sebab sudah sangat sesuai dengan background Indonesia yang majemuk.

Pancasila yang berisi lima sila atau dasar negara, berbunyi;

1. Ketuhanan Yang Maha Esa

2. Kemanusiaan yang beradab

3. Persatuan Indonesia

4. Kerakyatan yang dipimpin oleh hikmad kebijaksanaan dalam permusyawaratan perwakilan

5. Keadilan sosial bagi seluruh rakyat Indonesia.

Dalam persidangan BPUPKI pada juni 1945, para pendiri bangsa sempat menemui dilema dalam menentukan dasar negara, apakah Islam atau Pancasila. Dalam Piagam Jakarta, Presiden pertama Indonesia, Soekarno, menyatakan isi dari sila pertama Pancasila dengan bunyi; "Ketuhanan Yang Maha Esa dengan kewajiban menjalankan Syari'at Islam bagi pemeluknya", ditolak oleh sekelompok anak muda yang menyatakan jika sila pertama isinya demikian, maka Kaum Nasrani dari Indonesia Timur tidak akan bergabung dengan Republik Indonesia (Sila Pertama Pancasila dalam Pusaran Sejarah Bangsa, tebuireng.online, 2019).

Terkait redaksi kalimat yang diajukan Soekarno pada sila pertama Pancasila tersebut, terjadi perdebatan antara golongan Islam dan golongan Nasionalis (merdeka.com; Ini Isi Pancasila Pertama Versi Soekarno, Beda dengan Sekarang; 2016). Tentu saja terjadi perdebatan, sebab dengan menukil kata 'Syariat Islam' memberi kesan seolah Indonesia bakal digiring menjadi Negara Islam. Sementara pada kata berikutnya, 'bagi pemelukpemeluknya' seolah memberi kesan kontradiksi terhadap inklusifitas, pancasila hanya untuk golongan tertentu, dalam hal ini adalah pemeluk islam. Sedangkan komposisi Indonesia bukan hanya orang islam saja, sekalipun memang mendominasi. Dalam perjuangan merebut kemerdekaan pun, Indonesia berpegangan bersama-sama antar lintas agama, bukan islam saja. Maka wajar jika sila pertama pancasila dalam Piagam Jakarta sempat menemui polemik.

Sehingga dalam PPKI pada 18 agustus 1945 terjadi revisi terhadap bunyi sila pertama pancasila yang diusulkan oleh Mohammad Hatta dari "Ketuhanan Yang Maha Esa dengan kewajiban menjalankan Syari'at Islam bagi pemeluknya" menjadi "Ketuhanan Yang Maha Esa" saja, sehingga rumusan Pancasila versi 18 agustus 1945 itu menjadi seperti yang dikenal saat ini (Perubahan Urutan Pancasila dan Perdebatan "Syariat Islam" di Piagam Jakarta, nasional.kompas.com, 2016). Penghapusan tujuh kalimat pada sila pertama pancasila menunjukkan jati diri bangsa Indonesia yang beragam dan bisa saling menghargai perbedaan.

Pancasila versi revisi bahkan sebelum benar-benar disahkan, Bung Karno sempat meminta pendapat dan persetujuan $\mathrm{KH}$. Hasyim Asy'ari selaku ulama terkemuka sekaligus pendiri organisasi Nahdlatul Ulama, menyerahkan keputusan terkait apakah Pancasila sudah sesuai syari'at dan nilai-nilai ajaran islam atau belum. 
Pesan Soekarno atas pentashihan Pancasila disampaikan oleh rombongan yang menemui Kiyai Hasyim di Jombang. Dalam rombongan tersebut, K.H Wahid Hasyim yang tidak lain adalah anak Kiyai Hasyim sendiri yang menghaturkan maksud kedatangan rombongan.

Setelah mendengar maksud dari kedatangan rombongan, Kiyai Hasyim tidak seketika memberikan keputusan. Kiyai Hasyim dalam prinsipnya memahami jika kemerdekaan adalah kemaslahatan bagi seluruh rakyat Indonesia, sementara perpecahan merupakan kerusakan (mafsadah) sehingga dasar Negara harus berprinsip menyatukan semua.

Bukan hanya berpegang pada prinsip personal, demi memberikan keputusan tentang Pancasila yang dihaturkan Bung Karno, Kiyai Hasyim bahkan juga melewati tirakat dengan berpuasa selama tiga hari. Selama puasa, beliau menghatamkan alQur'an dan membaca surat al-Fatihah. Beliau mengulangi 350.000 kali ketika sampai pada ayat iya kana' budu waiya kanasta'in. Usai puasa selama tiga hari, Kiyai Hasyim melakukan salat istikharah dua rakaat. Dalam rakaat pertama, beliau membaca Surat atTaubah 41 kali dan di rakaat kedua, beliau membaca surat al-Kahfi sebanyak 41 kali. Setelsh itu beliau tidur dengan membaca ayat terakhir dari surat al-Kahfi sebanyak 11 kali seebelum tidur. Pagi harinya, beliau memanggil Kiyai Wahid dan mengatakan jika Pancasila versi revisi sudah benar, sudah pas, tanpa bertentangan dengan nilai-nilai serta prinsip ajaran islam (Peneguhan Pancasila di Tangan Hadratus Syekh dan Gus Dur; radarbangsa.com, 2018). Atas ikhtiyar lahir batin Kiyai Hasyim tersebut, Pancasila menjad i dasar Negara sekaligus pemersatu bangsa hingga kini.

Di awal 1980-an, Orde Baru mewacanakan Pancasila sebagai Asas Tunggal Negara. Ternyata NU melalui beberapa kiyai sepuh serta tokoh-tokoh mudanya menerima Asas Tunggal Pancasila (Tim Aswaja NU Center PWNU Jawa Timur, 2016). Sementara pada Muktamar NU ke-27 yang berlangsung di Situbondo pada tahun 1984, NU membuat keputusan atau lebih menegaskan bahwa NU berasaskan Pancasila (Peran dan Perjuangan Nahdlatul Ulama (NU) Masa Kemerdekaan, wawasansejarah.com, 2016). NU sepenuhnya menerima dan mendukung Pancasila, sebab bagi para kiyai, Pancasila bukanlah agama, tetapi falsafah hidup yang sudah sangat pas dan sesuai untuk Indonesia serta tidak bertentangan dengan prinsipprinsip islam.

Pancasila adalah rahasia dapur, mengapa sekalipun Indonesia menjadi Negara berpenduduk muslim terbesar di dunia, tetapi tetap brsatu dengan keragaman dan perbedaan. Pancasila yang sejak awal sudah mendapat restu dari ulama yang bukan sekadar ulama, pendiri organisasi islam terbesar yang secara tidak langsung mendapat petunjuk dari Tuhan.

\section{NU dan Ormas pro Khilafah}

Indonesia merupakan Negara besar ke4 dengan muslim terbanyak di dunia. Realitas tersebut berpengaruh pada kuantitas organisasi massa yang ada di Indonesia sendiri. Berdasarkan catatan Wikipedia, ada beberapa organisasi masyarakat (ormas) Islam yang tersebar di Indonesia, di antaranya adalah Nahdlatul Ulama (NU), 
Muhammadiyyah, Front Pembela Islam (FPI), dan lain-lain.

Keberadaan multi-ormas Islam di Indonesia bukan suatu persoalan selama itu tidak menimbulkan gangguan terhadap stabilitas nasional serta tidak ada potensi penghianatan terhadap Negara, misalnya seperti makar atau upaya merongrong kedaulatan serta ideology Negara.

Menyoal organisasi masyarakat (ormas) sendiri, Indonesia telah mengeluarkan Peraturan Pemerintah Pengganti Undang-Undang Nomor 2 Tahun 2017 tentang Organisasi Kemasyarakatan (Perppu Ormas) yang telah disahkan menjadi undang-undang (UU).

Dikutip dari detik news, dalam Perppu Ormas yang telah disahkan menjadi UU, bentuk larangan bagi Omas di Indonesia semakin diperluas dari aturan sebelumnya, di antaranya adalah soal definisi paham yang bertentangan dengan Pancasila. Selain itu, Menteri Hukum dan HAM punya kewenangan langsung membubarkan ormas anti-Pancasila. Pencabutan badan hukum terhadap ormas yang asas serta kegiatannya nyata-nyata mengancam kedaulatan NKRI berdasarkan Pancasila dan UUD 1945 bisa dilakukan secara langsung oleh Menteri Hukum dan HAM (Sah Jadi UU, Ini Isi Lengkap Perppu Ormas, detiknews, 2017).

Undang-Undang tersebut memang sangat dipelukan demi melindungi Negara dari organisasi-organisasi yang dapat mengancam keutuhan serta perdamaian bangsa. Tidak sembarang organisasi bisa didirikan, apalagi jika berpotensi mengancam Pancasila. Sebab arus organisasi dalam menjaring serta memengaruhi massa dapat bergulir dengan sangat cepat, apalagi yang dengan mengatasnakan agama (Islam).

Fenomena penegakan Khilafah di Indonesia didengungkan cukup gencar belakangan. Ada sekelompok organisasi masyarakat yang berupaya menegakkan Khilafah di Indonesia, sementara Khilafah sendiri bertentangan serta bertolak belakang dengan Pancasila.

Menurut Wikipedia, Khilafah didefinisikan sebagai sebuah sistem kepemimpinan umum bagi seluruh kaum muslim di dunia untuk menerapkan hukumhukum Islam dan mengemban dakwah Islam ke seluruh penjuru dunia. Orang yang memimpin disebut Khalifah.

Dari definisi tersebut, jelas Khilafah tidak sesuai jika diterapkan di Indonesia. Menerapkan sistem kekhalifahan berarti menjadikan sebuah Negara sebagai Negara Islam, sementara Indonesia terdiri dari berbagai agama yang berbeda sekalipun Islam mendominasi.

Apakah sistem kekhalifahan (Khilafah) berarti buruk? Tidak, tentu saja tidak. Khilafah bukan jalan buruk untuk dijadikan sebagai asas dan dasar sebuah Negara, tetapi sayangnya, di al-Qur'an sendiri belum ditemukan bab yang membahas tentang Khilafah. Nabi Muhammad sendiri tidak pernah mengajarkan Khilafah dalam membentuk Negara, tetapi mengajarkan konsep Madani-Madinah, suku-suku dan kabilah-kabilah hidup berdampingan dengan rukun. Bahkan, sejarah sudah mencatat belum ada suatu negara di dunia ini yang mengalami keberhasilan berkat menerapkan sistem ke-Khalifahan. Justru yang ada, gesekan demi gesekan yang terjadi secara massif dan global, sesama muslim dan ulama 
saling tuduh, serang, dan menyalahkan. Negara-negara konflik di Timur Tengah, saya rasa menjadi bukti yang bicara terkait kegagalan khilafah.

Ideologi negara dengan paham keagamaan selamanya tidak dapat disatupadukan. Bernegara tanpa perlu menyeret-nyeret agama, begitu juga sebaliknya. Maka sebagai pengamat dan penulis, saya dibuat cukup heran dengan segelintir orang yang bersikeras tentang penegakan Khilafah di Indonesia. Orangorang demikian bahkan berani berbuat makar, melakukan tindak instabilitas yang justru memicu perpecahan, dan menjadikan agama sekadar alat demi menjustifikasi orang sekehenda hati. Dengan membawa nama agama, seolah Tuhan pun berpihak padanya.

Dengan Khilafah, sebuah negara hanya diajarkan tentang konsep ke-agamaan, Amanu Wa Amilu as-Shalihat, tetapi menanggalkan konsep bernegara, Wa Hadzal Baladil Amin. Indonesia? Melalui Pancasila dapat mengimbangkan konsep keagamaan dan kebernegaraan.

Amanu Wa Amilu as-Shalihat sesuai dengan Sila pertama Pancasila, Ketuhanan Yang Maha Esa. Dan Wa Hadzal Baladil Amin, sebagaimana sila ke-tiga Persatuan Indonesia. Jadi, tidak ada yang dapat mengusik Pancasila. Pancasila adalah harga mati.

Sebagai organisasi islam terbesar, Nahdlatul Ulama akan terus mengawal terpeliharanya Pancasila di Indonesia, dari sejak dibentuk, hingga kini, dan sampai kapanpun. Realita yang tak terbantah, Ulama-Ulama Nahdlatul Ulama tidak sedikit yang (pernah) mengenyam pendidikan agama di luar negeri seperti di Makkah,
Madinah, Kairo, maupun Negara-negara kiblat Islam lainnya, tetapi bukan berarti sepulang ke tanah air Indonesia mereka juga sekaligus membawa budaya luar, memaksakan budaya asing untuk diimplementasikan di Indonesia, tidak.

\section{NU dan Islam Nusantara sebagai referensi bagi perdamaian dunia}

Nahdlatul Ulama selalu mengampanyekan Islam Nusantara demi perdamaian bangsa. Islam Nusantara yang dipelopori Nahdlatul Ulama ingin membawa pesan damai dengan mengenalkan Islam sebagai agama yang rahmatan lil alamin (rahmat bagi seluruh alam), bukan sebatas rahmatan lil muslimin (rahmat bagi orangorang muslim saja).

Islam Nusantara merupakan pemikiran yang berlandaskan sejarah masuknya Islam ke Indonesia yang tidak melalui peperangan, serta kekerasan, maupun doktrin yang kaku, melainkan melalui pendekatan budaya. Jadi, Islam Nusantara bukan aliran, sekte, mazhab, atau apalagi agama baru, melainkan tipologi Islam, yang mana Islam harus menyatu dengan nasionalisme yang berlandaskan pada spirit keIslaman.

Berdirinya Nahdlatul Ulama sendiri bermula dari keinginan para ulama untuk mengawal terjaganya Islam Nusantara. Sedangkan Islam Nusantara merupakan bagian dari ciri khas Islam di Indonesia yang mengedepankan nilai toleransi, moderat, dan bertolak belakang dengan Islam Arab.

Sebagaimana yang pernah disampaikan KH. Said Aqil Siraj selaku ketua PBNU (Pengurus Besar Nahdlatul Ulama periode 2010-2020) kepada BBC Indonesia sewaktu Pembukaan Munas Ulama pada 2015 silam, bahwa Islam Nusantara didakwahkan dengan 
merangkul, melestarikan, serta menghormati budaya, selagi tidak bertentangan syari'at. Bukan malah memberangus budaya.

NU akan terus mempertahankan karakter Islam Nusantara, yakni Islam yang ramah, anti-radikal, inklusif, toleran, dan tentu berbeda dengan Islam Arab yang identik dengan pemaksaan, kekerasan, perang saudara, maupun konflik dengan sesama Islam. Demikian tegas Kiyai Said.

Senada dengan Kiyai Said, cendekiawan muslim Azyumardi Azra juga mengatakan jika model Islam Nusantara memang dibutuhkan oleh masyarakat Indonesia, terutama masyarakat dunia dewasa ini, dengan ciri khasnya yang mengedepankan jalan tengah, moderat (tawassuth), tidak ekstrim kanan dan kiri, selalu seimbang, inklusif, toleran, bisa hidup berdampingan dengan penganut agama lain, serta bisa menerima demokrasi dengan baik. (Polemik di Balik Istilah 'Islam Nusantara', bbc.com, 2015).

Ada perbedaan antara Islam Indonesia dengan Islam Timur Tengah, terutama dari segi sosio-kultural dan politik, maka sebenarnya model Islam Nusantara menegaskan tentang fleksibilitas dan relevansi yang sebenarnya model demikian telah dibawa sejak Islam kali pertama masuk Indonesia, terutama pada masa dakwah Wali Songo.

Ada pandangan yang menyebutkan jika dakwahWali Sanga merupakan yang paling sukses dan berhasil, sebab mampu mengislamkan masyarakat Jawa. Bukan hanya karena waktu dalam penyebaran atau mendakwahkan Islam dalam tempo yang terbilang panjang, yakni sejak abad ke-7 hingga sekitar abad ke-14, tetapi juga karena beberapa strategi dan pendekatan terbukti teruji.

Setidaknya ada lima pendekatan dakwah yang digunakan oleh Wali Sanga, di antaranya pendekatan teologis, pendekatan ilmiah, pendekatan kelembagaan, pendekatan social, dan pendekatan cultural (budaya). (Lima Pendekatan Dakwah Wali Sanga, nu.online, 2018).

Maka bukan hal yang mengherankan jika Wali Sanga menggunakan media sya'ir, tembang, alat music dalam mendakwahkan Islam. Wali Sanga juga tidak hanya menyasar golongan atas, tetapi juga merangkul dengan ramah kelas menengah ke bawah atau popular dengan sebutan Waisya Sudra.

Tidak heran jika peninggalan Wali Sanga pun tak sedikit yang bercorak HinduBudha yang mana merupakan kepercayaan sebagian masyarakat Indonesia kala itu. Contohnya, Masjid Menara Kudus yang lebih mirip candi khas Jawa Timur, bahkan ada yang menyebut mirip Bale Kulkul, atau bangunan penyimpan kentongan di Bali (Masjid Menara Kudus, Saksi "Hidup" Toleransi dari Masa ke Masa (1), kompas.com, 2018)

Sebenarnya selain Masjid Menara Kudus ada banyak peninggalan Wali Sanga yang menyiratkan nilai toleransi, perwujudan tepa selira atau tenggang rasa, serta apresiasi pada budaya setempat. Begitulah cara Wali Sanga dalam berdakwah yang terbukti jitu mensyiarkan Islam dengan cara santun, damai, serta sedikitpun tanpa adanya kekerasan. Dan melalui Islam Nusantara, Nahdlatul Ulama mencoba melestarikan serta mengadaptasi pendekatan juga strategi Wali Sanga dalam menciptakn perdamaian, mengaplikasikan Islam Ahlus Sunnah Wal 
Jama'ah tanpa mengusik budaya juga kearifan lokal setempat.

Islam Nusantara ala Nahdlatul Ulama adalah referensi bagi Negara-negara dalam mengusahakan perdamaian dunia yang sudah teruji secara teoritis maupun dalam praktiknya.

\section{Cara berdakwah ala Aswaja an- Nahdliyyah}

Ahlussunnah wal jama'ah Nahdlatul Ulama, organisasi anti radikalisme yang selalu mengedepankan sikap tasamuh (toleran), tawazun (seimbang), I'tidal (tegak lurus), tawasuth (moderat) dalam segala hal, termasuk dalam berdakwah dan Amar Ma'ruf Nahi Munkar. Tidak terlalu ekstrem kanan yang cenderung radikal, maupun ekstrem kiri yang cenderung liberal. Netral, santun, ramah, dan merangkul.

Dewasa ini munculnya pendakwah di tengah-tengah masyarakat yang mudah mengakses informasi merupakan fenomena baru yang tidak lagi asing. Asal bersorban dan memiliki jamaah, seseorag bisa dengan mudah dipanggil kiyai, ustad, gus, atau guru. Tidak peduli apakah seseorang tersebut mumpuni secara keilmuan atau tidak. Tentu fenomena ini perlu diwaspadai agar kita tidak salah jalan sehingga dapat memengaruhi mindset maupun pemikiran kita terkait agama itu sendiri.

Di bawah ini adalah ciri-ciri pendakwah Ahlussunnah wal Jama'ah annahdliyyah yang perlu diketahui: Pertama. Tidak Keras, Ulama Aswaja An-nahdliyyah berdakwah dengan cara ramah, lembut, dan fleksibel menyesuaikan dengan kondisi masyarakat. Tidak frontal dan asal mengharamkan sana sini. Cara berdakwah serta menuntun masyaraat dilakukan dengan runut pun bertahap. Tidak jarang juga menyelipkan humor agar suasana dakwah lebih relax, bukan penuh keseriusan dengan pembawaan kaku atau bahkan membentakbentak.

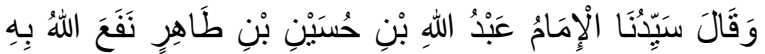

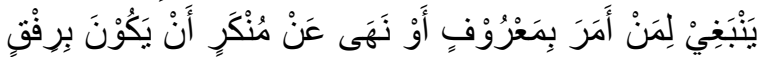

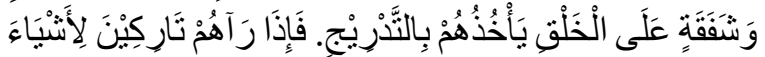

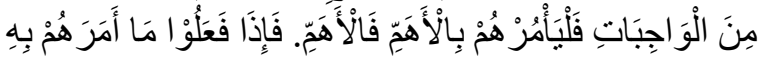

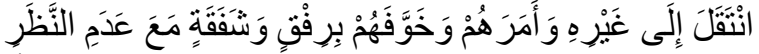

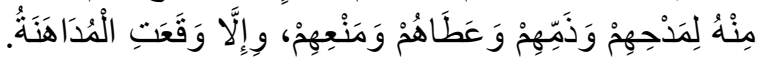

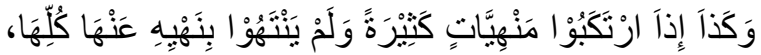

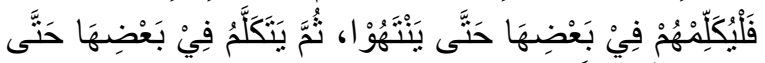

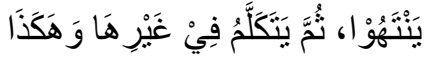

Artinya; Habib Abdullah bin Husain bin Tahir mengatakan bahwa sebaiknya orang yang menyeru kebaikan dan mencegah kemungkaran melakukannya dengan halus dan penuh kasih saying kepada makhluk. Mereka menuntunnya dengan bertahap. Apabila masyarakat meninggalkan banyak kewajiban, maka prioritaskanlah mereka dengan kewajiban yang paling urgen. Jika mereka sudah mampu menjalankan satu kewajiban, maka baru berpindah kepada kewajiban yang lain.

Dan memerintahkan serta memberinya peringatan dengan lembut dan kasih saying dengan tidak memedulikan sanjungan, cacian serta pemberian mereka. Bila tidak demikian, maka akan terjadi mudahanah (penipuan/mengambil muka). Demikian pula jika masyarakat melakukan banyak kemunkaran dan tidak dapat meninggalkan keseluruhannya, maka cegahlah sebagiannya sampai mereka mampu meninggalkan. Kemudian beralih pada persoalan lain sehingga mereka meninggalkannya, dan demikian seterusnya" (Habib Zain, 2008). 
Kedua. Tidak men-judge kafir dan munafik atas oranglain. Bisa dibayangkan jika seorang ulama pendakwah mudah memvonis oranglain dengan tuduhan miring, gemar melontarkan dan men-judge kafir atau munafik, maka tentu selain citra agama menjadi ternista, orang justru enggan mendekat. Dan lebih dari itu, agama sendiri tak mengajarkan hal demikian. Kafir dan munafiknya seseorang adalah hak prerogative Tuhan dalam menghukumi.

Islam adalah agama yang santun dan lembut baik dalam tindakan maupun perkataan, ramah serta toleran, sebagaimana yang diajarkan Nabi Muhammad SAW. Dan cara Nabi yang demikian itulah yang diterapkan oleh ulama Aswaja AnNahdliyyah dalam berdakwah, mensyiarkan serta mengajak pada kebaikan (amar ma'ruf nahi munkar).

Syekh Nawawi bin Umar al-Bantani mengatakan;

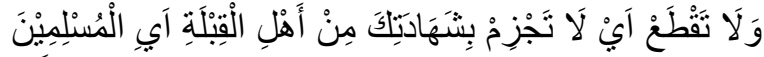

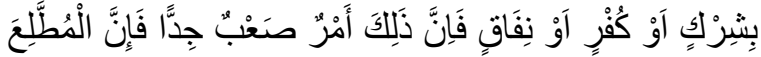

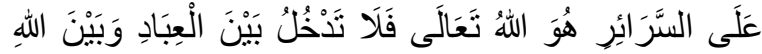

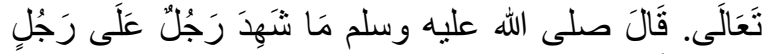

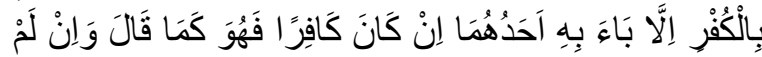

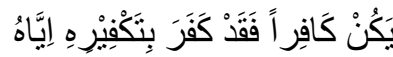

Artinya; "Janganlah memastikan kesaksianmu atas orang Islam dengan syirik, kufur, atau munafik. Karena sesungguhnya hal tersebut perkara yang sangat berat. Sesungguhnya yang dapat mengetahui beberapa isi hati adalah Allah, maka engkau tidak bisa ikut campur urusan pribadi hamba dan Tuhannya. Nabi SAW bersabda, tidaklah seseorang bersaksi kafir kepada oranglain, kecuali vonis kafir tersebut kembali kepada salah satunya. Jika yang dituduh betul kafir, maka benar seperti apa yang dituduhkan. Jika yang dituduh tidak kafir, maka sungguh yang menuduh telah kafir karena mengkafirkan pihak yang dituduh kafir" (Syekh Nawawi alBantani, Maraqil Ubudiyyah; 69)

Syekh Abu Manshur Al-Baghdadi, alFarq Baina al-Firaq mengatakan;

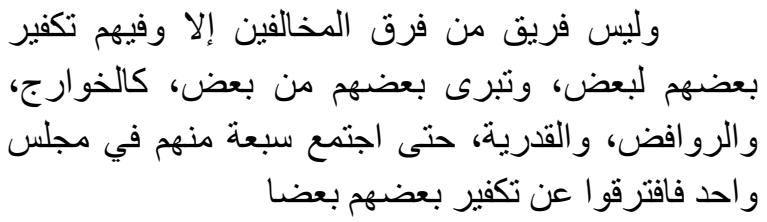

Artinya; "Tidak ada satu pun golongan di luar Ahlussunnah wal Jama'ah, kecuali di antara mereka saling mengafirkan dan memutus hubungan, seperti Khawarij, Syiah, dan Qadariyah (Mu'tazilah). Sehingga pernah suatu ketika, tujuh orang dari mereka berkumpul dalam satu majelis, lalu mereka berbeda pendapat dan mereka berpisah dengan saling mengafirkan antara mereka." (Tim Aswaja NU Center PWNU Jawa Timur, 2016).

Ketiga. Tidak menentang/ memberontak/ makar terhadap pemerintah. Berdasarkan kesepakatan Ulama, tindakan memberontak terhadap pemerintah yang sah adalah haram sekalipun pemerintah tersebut fasik atau zalim.

Syekh Al-Imam An-Nawawi menegaskan:

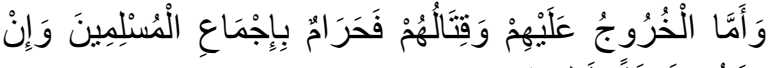

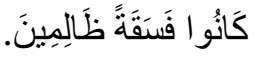

Artinya; "Adapun keluar dari ketaatan terhadap penyelanggara negara dan memeranginya maka hukumnya haram berdasarkan ijma' ulama, meskipun mereka fasik dan zalim" (An-Nawawi, al-Minhaj Syarh Shahih Muslim bin al-Hajjaj, Beirut, Daru Ihya'it Turats, 1392 H, juz XXII, hal. 229) 
Ulama Aswaja an-Nahdliyyah tidak berdakwah dalam keadaan memberontak, menentang atau makar terhadap pemerintah yang sah, apalagi menuduh maupun mengadu domba terhadap pemimpinnya. Dalam sejarah perjalanan dakwahnya pun demikian.

Andaipun ditemukan kekeliruan dari kebijakan pemerintah, maka member nasihatnya pun dengan santun, bijak, serta sesuai konstitusi, sebagaimana sabda Rasulullah SAW;

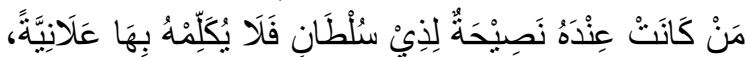

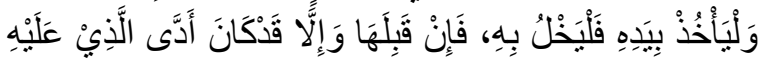
وَالَّذِيْ لَلَهُ

Artinya; "Barangsiapa hendak menasihati pemerintah, maka janganlah dengan terang-terangan di tempat terbuka. Namun, jabatlah tangannya, ajaklah bicara di tempat tertutup. Bila nasihatnya diterima, maka bersyukurlah. Bila tidak diterima, maka tidak mengapa, sebab sungguh ia telah memenuhi kewajibannya dan haknya" (HR. al-Hakim, Shahih).

Keempat. Tidak fanatik buta. Tidak fanatik secara berlebih, artinya dapat menghargai perbedaan. Bukan sekadar kelompoknya saja yang dianggap paling benar. Dalam setiap perbedaan yang bersifat furu'iyyah, pendakwah Aswaja anNahdliyyah tidak gampang klaim sesat atau fasik kepada pihak lain.

Ciri khas Aswaja yang tidak fanatik buta ini sebagaimana dikatakan Syekh Abdul Qahir al-Baghdadi berikut;

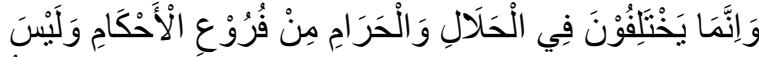

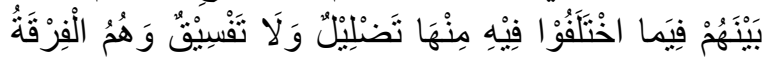
النَّاجيَنُة

Artinya; "Dan mereka hanya berbeda dalam halal dan haram dari beberapa cabangan hukum. Tidak ditemukan dalam perbedaan di antara mereka vonis penyesatan dan tuduhan fasiq, mereka adalah kelompok yang selamat" (Syekh Abdul Qahir, 1977)

Demikianlah beberapa ciri dakwah ala Aswaja An-Nahdliyyah yang ramah, santun, dapat menghargai perbedaan, toleran, tidak memaksakan kehendak, tidak mudah menggunakan tutur kata untuk mejustifikasi miring atas oranglain, serta menghormati pemerintah, sehingga terciptalah suasana dakwah yang harmonis, menyenangkan, serta dapat diterima semua kalangan.

\section{Pemikiran radikal dan liberal yang mampu diatasi dengan 4 prinsip dasar} NU

Menurut Kamus Besar Bahasa Indonesia arti radikal adalah amat keras menuntut perubahan (undang-undang, pmerintahan). Sementara radikalisme berarti paham atau aliran yang radikal dalam politik, paham atau aliran yang menginginkan perubahan atau pembaharuan sosial dan politik dengan cara kekerasan atau drastis, bisa juga dimaknai dengan sikap ekstrem dalam aliran politik. Dan pada kesimpulannya, setiap kita mendengar kata radikal, maka pasti merujuk pada sesuatu yang memberi kesan keras, brutal, tidak jarang dikait-kaitkan dengan terorisme.

Sementara makna liberal atau liberalisme menurut Wikipedia adalah sebuah ideologi, pandangan filsafat, dan tradisi politik yang didasarkan pada pemahaman bahwa kebebasan dan persamaan hak adalah nilai politik yang utama. Secara umum, liberalisme mencitacitakan suatu masyarakat yang bebas, dicirikan oleh kebebasan berpikir bagi para individu. Paham ini menolak adanya 
pembatasan, khususnya dari pemerintah dan agama.

Bergembangnya gerakan radikalisme yang cenderung keras dan liberalisme yang lebih menganut pada kebebasan atau pemikiran yang menganggap semua boleh, adalah gerakan-gerakan berbahaya yang sama-sama patut diatasi dengan baik.

Oleh sebab itu Nahdlatul Ulama hadir di tengah masyarakat member solusi untuk mengatasi isu radikalisme dan liberalism yang semakin liar dengan mengusung prinsip-prinsip jalan tengah yang selama ini dipegang erat, yakni Tawassuth (moderat), I'tidal (adil), Tasammuh (toleran), Tawazun (seimbang), serta Amar Ma'ruf Nahi Munkar.

Tawassuth berarti sikap tengah-tengah atau mengambil jalan tengah. Sementara I'tidal bermakna tegak lurus, adil, tidak berpihak kecuali kepada yang benar. Nahdlatul Ulama dengan kedua prinsip dasar ini akan selalu menjadi panutan karena bersifat membangun serta menghindari segala bentuk pendekatan yang bersifat tatharruf (ekstrem).

Tasammuh adalah sikap menghargai perbedaan serta menghormati oranglain yang berpandangan hidup berbeda. Sikap tasammuh atau bertoleransi ini dapat ditunjukkan dalam menyikapi perbedaan pandangan, baik dalam masalah kemasyarakatan, kebudayaan, maupun keagamaan, terutama yang bersifat furu' atau menjadi masalah khilafiyyah.

Tawazun bermakna seimbang, maksudnya tidak berlebihan dalam berhubungn, baik antar individu, antar struktur sosial, antar negara dan rakyatnya. Tidak pula berat sebelah, dalam artian, seimbang dalam berhubungan baik secara vertikal (hablun min Allah), maupun secara horizontal (hablun min an-Nas). Selaras, fleksibel, dan relevan dalam menyikapi kepentingan masa lalu, masa kini, serta masa mendatang.

Senantiasa mendorong perilaku dalam mengajak terhadap kebaikan serta bermanfaat bagi kehidupan bersama dan senantiasa menolak segala hal yang dapat menjerumuskan dan merendahkan nilai-nilai kehidupan. (bangkitmedia.com, Empat Prinsip Dasar Nahdlatul Ulama, 2020).

Dengan demikian Nahdlatul Ulama yang berlandaskan Ahlussunnah Wal Jama'ah harus memegang prinsip Tawassuth, I'tidal, Tasammuh, Tawazun, serta Amar Ma'ruf Nahi Munkar yang dapat menjadi benteng dari gerakan radikalisme maupun liberalisme.

Berikut implementasi prinsip Tawassuth, Tawazun, dan I'tidal dalam upaya deradikalisasi dan deliberalisasi;

a. Memadukan operasionalisasi dalil aqli dan naqli dengan tetap menempatkan dalil aqli di bawah dalil naqli; atau dalam ungkapan lain mendudukkan rasio secara proporsional, tidak menolaksama sekali penggunaan rasio melebihi nash, tekstualkontekstual seimbang, tidak liberal.

b. Dalam memahami sifat Allah tidak ta'thil (mengingkari sifat-sifat Allah seperti yang dilakukan Kaum Mu'atthilah), tidak tajsim (menggambarkan Allah mempunyai organ tubuh seperti Kaum Mujassimah), dan tidak tasybih (menyerupakan Allah dengan makhluk seperti Kaum Musyabbihah). 
c. Berpegang teguh pada al-Qur'an dan asSunnah dengan cara mengikuti mazhab dan manhaj ulama mazhab empat.

d. Bersikap toleran pada masalah-masalah furu'iyyah.

e. Meninggalkan sikap ghuluw (berlebihan) dan tatharruf (ekstrim).

f. Menerima hal-hal baru baik berkaitan dengan budaya atau pemikiran dari luar sepanjang tidak bertentangan dengan syari'at.

g. Menjalankan agama secara proporsional antara ukhrawi dan duniawi serta seiring antara syariat dan hakikat.

h. Seimbang antara ikhtiar (memilih), usaha, dan tawakkal.

i. Bersikap hati-hati dalam menjatuhkan vonis kafir, sesat, dan semisalnya.

j. Mendudukkan secara jelas antara sifat kehambaan dan ketuhanan. (Tim Aswaja NU Center PWNU Jawa Timur, 2016)

\section{Mengapa harus Nahdlatul Ulama?}

Di penghujung pembahasan ini, kita semua mulai mendapat gambaran mengenai peran Nahdlatul Ulama dalam menciptakan perdamaian di Indonesia khususnya, dan dunia pada umumnya. Pada prinsipnya, Nahdlatul Ulama merupakan organisasi Islam yang besar, tetapi mampu merangkul semua kalangan. Kualitas maupun kuantitas yang dimiliki Nahdlatul Ulama, tidak menjadikan ormas anti radikalisme ini mengangkat tinggi arogansi.

Nahdlatul Ulama dapat diterima siapapun, dari kalangan manapun, dari masa ke masa. Tak ayal jika pada akhirnya Nahdlatul Ulama menjadi magnet bagi tokok-tokoh dunia guna mengenal lebih dekat organisasi yang relevan sebagai rujukan bagi terciptanya perdamaian dunia ini.

Melalui Ketua Umum PBNU KH. Said Aqil Siraj, NU mencetuskan deklarasi untuk menginspirasi perdamaian dunia, yakni ajakan serta strategi membangun perdamaian di level internasional. Pada penutupan agenda International Summit of the Moderate Islamic Leaders yang diadakan pada 2016 lalu, Kiyai Said, di hadapan ratusan ulama dan cendekiawan berbagai negara, menegaskan bahwa sudah saatnya negara muslim bersatu untuk menghadirkan kedamaian di seluruh dunia. Deklarasi Nahdlatul Ulama menyerukan pentingnya persatuan (ukhuwah) di antara kaum muslim.

Selain itu, Nahdlatul Ulama juga mengajak ulama seluruh dunia juga tokoh lintas agama untuk menjaga perdamaian. Deklarasi ini juga menyampaikan pentingnya konsep nilai Islam Nusantara yang nilai etik dan semangatnya, dapat menjadi inspirasi perdamaian dunia.

Berikut poin-poin deklarasi Nahdlatul Ulama pada agenda International Summit of Moderate Islamic Leaders;

1. Nahdlatul Ulama menawarkan wawasan dan pengalaman Islam Nusantara kepada dunia sebagai paradigm Islam yang layak diteladani, bahwa agama menyumbang kepada peradaban dengan menghargai budaya yang telah ada serta mengedepankan hrmoni dan perdamaian.

2. NU tidak bermaksud mengekspor Islam Nusantara ke kawasan lain di dunia, tetapi sekadar mengajak komunitaskomunitas muslim lainnya untuk mengingat kembali keindahan dan kedinamisan yang terbit dari pertemuan 
sejarah antara semangat dan ajaranajaran islam dengan realitas budayabudaya local di seantero dunia, yang telah melahirkan beragam peradabanperadaban bear, sebagaimana di Nusantara.

3. Islam Nusantara bukanlah agama atau mazhab baru melainkan sekadar pengejawantahan Islam yang secara alami berkembang di tengah budaya Nusantara dan tidak bertentangan dengan Syari'at Islam sebagaimana dipahami, diajarkan, dan diamalkan oleh kaum Ahlussunnah wal Jama'ah di seluruh dunia.

4. Dalam cara pandang Islam Nusantara, tidak ada pertenntangan antara agama dan kebangsaan. Hubbul Wathan minal iman; "cinta tanah air bagian dari iman." Barangsiapa tidak memiliki kebangsaan, tidak akan memiliki tanah air. Barangsiapa tidak memiliki tanah air, tidak akan punya sejarah.

5. Dalam cara pandang Islam Nusantara, Islam tidak menggalang pemelukpemeluknya untuk menaklukkan dunia, tetapi mendorong untuk terus menerus berupaya menyempurnakan akhlaqul karimah, karena hanya dengan cara itulah Islam dapat sungguh-sungguh mewujud sebagai rahmat bagi semestaalam (Rahmatan lil alamin).

6. Islam Nusantara secara teguh mengikuti dan menghidupkan ajaran-ajaran dan nilai-nilai Islam yang mendasar, termasuk tawassuth (jalan tengah, yaitu jalan moderat), tawazun (keseimbangan; harmoni), tasamuh (kelemah-lembutan dan kasih saying, bukan kekerasan dan pmaksaan) dan I'tidal (keadilan).
7. Sebagai organisasi Aswaja terbesar di dunia, NU berbagi keprihatinan yang dirasakan oleh sebagian warga muslim dan non muslim di seluruh dunia, tentang merajalelanya ekstremisme agama, terror, konflik di Timur Tengah dan gelombang pasang Islamofobia di Barat.

8. NU menilai bahwa model-model tertentu dalam penafsiran Islamlah yang merupakan faktor paling berpengruh terhadap penyebaran ektremisme agama di kalangan umat islam.

9. Selama beberapa decade ini, berbagai pemerintah negara di Timur Tengah telah mengeksploitasi perbedaanperbedaan keagamaan dan sejarah permusuhan di antara aliran-aliran yang ada, tanpa mempertimbangkan akibatakibatnya terhadap kemanusiaan secara luas. Dengan cara mengembuskan perbedaan-perbedaan sectarian, negaranegara tersebut mmburu soft power (pengaruh opini) dan hard power (pengaruh politik, ekonomi serta militer) dan mengekspor konflik mereka ke seluruh dunia. Propaganda- propaganda sectarian tersebut dengna sengaja memupuk ekstremisme agama dan mendorong penyebaran terorisme ke seluruh dunia.

10. Penyebaran ekstremisme agama dan terorisme ini secara langsung berperan menciptakan gelombang pasang Islamofobia di kalangan non-muslim.

11. Pemerintahan negara-negara tertentu di Timur Tengah mendasarkan legitimasi politiknya diambil justru dari tafsir-tafsir keagamaan yang mendasari dan menggerakkan ekstremisme agama dan terror. Ancaman ekstremisme agama dan 
terror dapat diatasi hanya jika pemerintahan-pemerintahan tersebut bersedia mebuka diri dan membangun sumber-sumber alternative bagi legitimasi politik mereka.

12. NU siap membantu dalam upaya ini.

13. Realitas ketidakadilan ekonomi dan poitik serta kemiskinan missal di dunia islam turut menyumbang pula terhadap berkembangnya ekstremisme agama dan terorisme. Realitas tersebut senantiasa dijadikan bahan propaganda ekstremisme dan terorisme, sebagai bagian dari alas an keberadaannya dan untuk memperkuat ilusi masa depan yang dijanjikannya, maka masalah ketidakadilan dan kemiskinan ini tak dapat dipisahkan pula dari masalah ektremisme dan terorisme.

14. Walaupun maraknya konflik yang meminta korban tak terhitung jumlahnya di Timur Tengah seolah-olah tak dapat diselesaikan, kita tidak boleh memunggungi masalah ataupun berlepas diri dari mereka yang menjadi korban. NU mendesak pemerintah Indonesia untuk megambil peran aktif dan konstruktif dalam mencari jalan keluar bagi konflik multi-faset yang merajalela di Timur Tengah.

15. NU menyeru siapa saja yang memiliki I'tikad baik dari semua gama dan kebangsaan untuk bergabung dalam upaya membangun consensus global untuk tidak mempolitisasi islam sedemikian rupa untuk menyakiti sesame.

16. NU akan berjuang untuk mengonsolidasikan kaum Aswaja sedunia demi memperjuangkan terwujudnya dunia di mana islam dan kaum muslimin sungguh-sungguh menjadi pembawa kebaikan dab berkontribusi bagi kemaslahatan seluruh umat manusia.

\section{PENUTUP}

Nahdlatul Ulama (An-Nahdliyyah) berpaham Aswaja bagi perdamaian dunia, khususnya bagi Negara Indonesia dengan background kemajemukan serta keberagamannya. Indonesia menjadi negara demokrasi dengan segala perbedaan dan kemajemukan yang ada, tetapi tetap bersatu padu, menciptakan kedamaian dalam satu bingkai kebangsaan. Indonesia bisa menjadi role model bagi negara-negara di dunia, khususnya bagi negara konflik dengan isu agama, bahwa perdamaian dan persatuan adalah perlu demi menjaga keutuhan suatu bangsa, dan Indonesia telah membuktikan harmoni itu. Selain sebab ideologi Pancasila yang terbukti mampu menyatukan perbedaan, Indonesia juga memiliki organisasi sebesar Nahdlatul Ulama yang telah terbukti hadir menjawab tantangan perbedaan. Nahdlatul Ulama merupakan organisasi masyarakat yang ramah, tidak marah. Merangkul, bukan memukul. Keberadaannya di tengah masyarakat mampu menjadi oase yang menyejukkan, dan menjadi garda terdepan dalam menjaga perdamaian serta keutuhan bangsa, sebagaimana yang tertuang dalam butir prinsipprinsip yang selama ini Nahdlatul Ulama pegang teguh.

\section{DAFTAR PUSTAKA}

Ad Dimasyqy Al Utsmani, Ibni 'Abdillah Sadr Al Dien, Rahmat Al Ummah.

Al Farra, Imam Abi Muhammad Al Husain, Al Tahdzîb.

Al Fâsî, Abu Abdillah Muhammad bin Muhammad Al Madkhâl. 
Al Ghâzi, Syaikh Ibnu Qâsim - Al Bajuri, Ibrâhim, Hasyiyah Al Bajuri.

Al Iskandari al Saiwasi, Syaikh Kamâluddîn, Fath Al Qâdir.

Al Jamal, Syaikh Sulaimân. Hasyiyah al Jamal"

Al Jâziri, Syaikh Abdurrahman, "Fiqh 'Alâ Madzâhib al Arba'ah.

Al Mishriy al Dimyaty, Sayyid Abu Bakar. I'ânah al Thâlibîn.

Al 'Umrâni, Imam Yahyâ bin Abi Khaîr bin Sâlim, Al Bayân.

Cholil Nafis, M. (2015). Fikih Kebangsaan" mitra abadi pres.

Dahlan Thamrin. (2015). Filsafat Hukum Islam

Keputusan LBM PWNU Jawa Timur, (2020). Hukum terkait Covid-19.

Keputusan Tim Aswaja NU Center PWNU Jawa Timur, (2013). Risalah Ahlussunnah Wal-Jamaah.

Keputusan Tim Aswaja NU Center PWNU. (2016). Jawa Timur, Khazanah Aswaja.

Rumusan- Rumusan Fikih empat Madzhab PBNU. (2010). Ahkamul Fuqaha.

Sulaimân bin Umar bin Muhammad. Bujairomi 'Ala al Khatîb.

Syaikh As Sarqâwi, As Syarqâwi Syarh Al Tahrîr.

Tholhah Hasan. (2003). Ahlussunnah WalJama'ah Lantabora Pres-Jakarta.

Wahbah al Zauhayly, Al Fiqh Al Islami Wa Adillatuh. 